\title{
RESPON GURU IPA TERHADAP PEMBELAJARAN IPA BERINTEGRASI ETNOSAINS: STUDI PENDAHULUAN DI KABUPATEN BANGKALAN
}

\section{Wiwin Puspita Hadi ${ }^{1 *}$, Yunin Hidayati ${ }^{2}$, Irsad Rosidi ${ }^{3}$}

\author{
Univerversitas Trunojoyo Madura1, 2, 3 \\ *Corresponding Author: wiwin.puspitahadi@trunojoyo.ac.id
}

DOI: $10.24929 /$ lensa.v10i1.92

Received: 12 Maret 2020

Revised: 20 Mei 2020

Accepted: 20 Mei 2020

\begin{abstract}
ABSTRAK
Pengembangan kualitas pembelajaran untuk mencapai tujuan pendidikan nasional dan memenuhi tuntutan global yang sangat kompleks membutuhkan guru IPA yang profesional. Salah satu upaya untuk meningkatkan kualitas adalah menerapkan pembelajaran IPA berintegrasi etnosains. Tujuan penelitian adalah mengetahui respon guru IPA dalam melaksanakan pembelajaran IPA berintegrasi etnosains Penelitian melibatkan guru IPA di kabupaten Bangkalan. Instrumen pengumpulan data menggunakan data primer yaitu hasil pengisian angket oleh guru IPA. Hasil penelitian dianalisis secara deskriptif kuantitatif dan dipersentasekan. Berdasarkan hasil analisis menunjukkan bahwa pembelajaran berintegrasi etnosains merupakan model pembelajaran yang dapat dilaksanakan dengan mudah, semua konsep dapat dilakukan pembelajaran. Metode pembelajaran dilaksanakan dengan observasi, dan sumber belajar dari lingkungan serta penilaian dilakukan secara autentik.
\end{abstract}

\section{Kata Kunci:Respon, Guru, Pembelajaran, Etnosains}

\begin{abstract}
Development of the quality of learning to achieve national education goals and meet the global demands in science and technology required by a professional science teacher. One effort to improve quality is by implementing ethnographic integrated learning. The study involved science teachers in Bangkalan district. The aims was to know teachers response to develop ethnoscience learning. Data collection instruments used primary data in the form of data obtained directly based on filling out a questionnaire by a science teacher. Research data were collected and analyzed descriptively. The average percentage technique calculated analysis of in this study using descriptive analysis of the results of questionnaires by the teacher. The research produced data that integrated learning with ethnoscience showed that learning model showing is easy to implement, apply all subjects. Teaching methods are implemented by observation, and learning resources from the environment and authentic assesment
\end{abstract}

Keyword:Response, teacher, learning, Ethnoscience

\section{PENDAHULUAN}

Pengembangan kualitas pembelajaran untuk mencapai tujuan pendidikan nasional dan memenuhi tuntutan global yang kompleks membutuhkan guru IPA yang profesional. Pengembangan profesionalitas salah satunya adalah penerapan kegiatan pembelajaran di kelas yang inovatif. Pembelajaran yang inovatif yang berintegrasi dengan budaya yang menjadi kekayaan bangsa Indonesia. Model yang dapat diterapkan adalah pembelajaran berbasis budaya lokal. Jika dikaitkan dengan pengetahuan ilmiah yang dimiliki masyarakat maka disebut etnosains. Budaya didefinisikan sebagai cara hidup kelompok masyarakat tertentu dan diwariskan secara turun temurun(Atmojo, 2012). Pembelajaran yang berbasis kearifan lokal sangat penting dalam pengembangan 
karakter(I. W. Suastra, Jatmiko, Ristiati, \& Yasmini, 2017).Sistem pembelajaran yang dilakukan harus secara komprensif memadukan antara konsep-konsep dan potensi kearifan lokal yang ada di masyarakat. Selain itu, lingkungan alam dapat dimanfaatkan sebagai sumber belajar dengan mengaitkan antara pengetahuan masyarakat dan ilmu pengetahuan alam.

Madura salah satu pulau yang kaya dengan budaya masyarakat merupakan salah satu kekayaan bangsa Indonesia, yaitu biokonservasi terkait dengan kearifan lokal msayarakat (Hidayati, 2019), batik madura, petis madura (Hidayati, Yasir, Qomaria, \& Fikriyah, 2019), terasi madura(Hadi, Sari, Sugiarto, \& Mawaddah, 2019). Madura mempunyai kekayaan budaya dan pengetahuan masyarakat yang dapat digunakan dalam meningkatkan kualitas pembelajaran siswa. Bangkalan sebagai salah satu kabupaten yang ada di Pulau Madura. Bangkalan juga kaya dengan berbagai budaya dan kearifan lokal masyarakat seperti pembuatan batik gentongan Tanjung Bumi, pembuatan terasi macajah, dan pembuatan petis ikan khas Bangkalan, atau makanan Bungko khas Arosbaya Bangkalan. Semua konsep tersebut dapat diimplentasikan dalam kegiatan pembelajaran IPA berintegasi etnosains. Kreatifitas guru sangat diperlukan dalam mengintegrasikan pengetahuan asli masyarakat dengan konsep-konsep dalam IPA.

Guru sebagai salah satu komponen penting dalam pembelajaran yang mempunyai tugas membina budi pekerti, mentransfer ilmu pengetahuan baik hard skills maupun soft skills dan mengevaluasi peserta didik dituntut memiliki berbagai kompetensi. Berdasarkan undang-undang guru dan dosen, guru wajib memiliki empat kompetensi meliputi kompetensi pedagogik, kompetensi kepribadian, kompetensi sosial dan kompetensi profesional. Guru sebagai bagian penting dalam tercapainya kualitas pembelajaran harus selalu meningkatkan kompetensi dalam pembelajaran. Berbagai penelitian dilakukan untuk mengetahui kompetensi guru (Rahman, 2016), (NM, Susilawati, \& Patonah, 2011), (Anisa, Nanna, Sofyan, \& Kusnadi, 2019). Kompetensi guru sangat menentukan dalam pengelolaan dan keberhasilan kegiatan pembelajaran

Upaya meningkatkan pengelolaan pembelajaran salah satunya adalah mengintegrasikan pembelajaran IPA dengan nilai-nilai budaya lokal masyarakat. Pembelajaran IPA yang selama ini berlangsung bersifat teoritis dan kurang implementasi dalam kehidupan siswa sehingga pembelajaran akan menjadi kurang bermakna. Keanekaragaman budaya masih belum dieksplore dan dikembangkan sebagai sumber belajar dalam proses pembelajaran sains karena faktanya sebanyak $90 \%$ guru IPA menyatakan ingin mengembangkan pembelajaran yang berbasis budaya lokal dan etnosains, namun hanya sekitar $20 \%$ yang memiliki wawasan dan pengetahuan untuk mengembangkan (I Wayan Suastra, 2010). Implikasinya dalam kegiatan pembelajaran siswa belum tahu kaitan konsep IPA dengan proses pembuatan produk-produk di masyarakat. Kondisi ini menyebabkan pembelajaran IPA masih cenderung bersifat abstrak sehingga kemampuan siswa untuk mengintegrasikan pembelajaran dalam kehidupan sehari-hari masih lemah.

\section{METODE PENELITIAN}

Penelitian ini adalah penelitian survei jenis penelitan deskriptif yaitu dengan memberikan gambaran informasi tentang suatu gejala yang diperoleh pada saat berlangsungnya kegiatan pengambilan data. Subyek penelitian ini adalah Guru IPA di Sekolah Dasar di Kabupaten Bangkalan. Sampel penelitian diambil secara acak dengan mengambil sampel sebanyak 86 guru IPA. Instrumen pengumpulan data menggunakan data primer berupa data yang diperoleh langsung berdasarkan pengisian angket oleh guru IPA. Hasil penelitian dianalisis secara deskriptif. Teknik analisis data dilakukan dengan cara hasil angket guru dihitung dan dipersentase kemudian dideskripsikan berdasarkan literatur pendukung. Angket yang diberikan kepada guru meliputi indikator sebagai berikut (1) penerapan pembelajaran IPA berintegrasi etnosains; (2)pokok bahasan yang dapat diterapkan dengan pembelajaran etnosains; (3) metode pembelajaran yang diterapkan dalam pembelajaran berintegrasi etnosains; (4) sumber belajar yang dipergunakan; (5) model pembelajaran yang dapat diterapkan' (6) teknik penilaian. 


\section{HASIL DAN PEMBAHASAN}

Hasil angket yang telah diisi guru menunjukkan hasil yang diuraikan setiap aspek sebagai berikut

Pada angket aspek 1 yaitu penerapan pembelajaran IPA berintregrasi etnosains sebanyak $65 \%$ guru menjawab mudah dalam melaksanakan pembelajaran IPA berintegrasi etnosains sedangkan $36 \%$ menjawab sulit.

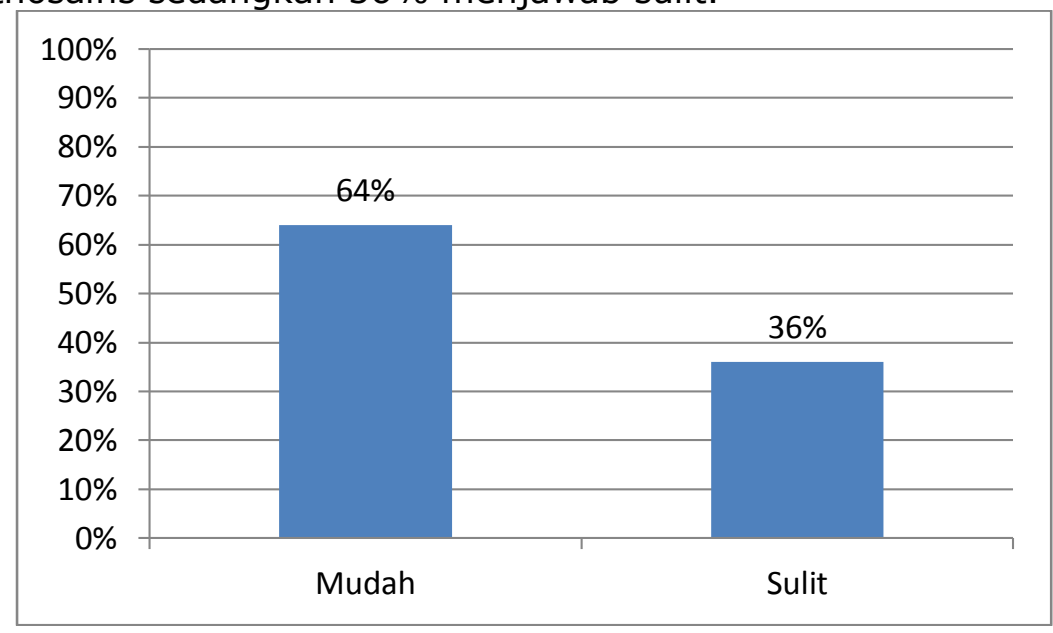

Gambar 1. Penerapan pembelaran IPA berintegrasi etnosains

Kemudahan pelaksanaan pembelajaran IPA berbasis etnosains berdasarkan hasil angket karena siswa dan guru sudah mengetahui kondisi lingkungan dan budaya masyarakat disekitar tempat tingga. sedangkan kesulitan dikarenakan masih terkendala sarana dan prasarana dan kurangnya kemampuan guru dalam melaksanakan pembelajaran IPA yang terintegrasi dengan budaya. Pengetahuan guru dalam melaksanakan pembelajaran etnosains juga masih tergolong sedang dan harus ditingkatkan (Septiasari, 2019)Pembelajaran IPA berintegrasi etnosains telah banyak dilakukan dalam kegiatan pembajaran. Pembelajaran etnosains dapat digunakan untuk mewujudkan karakter siswa(Yuliana, 2017).

Aspek kedua yaitu pokok bahasan yang dapat diterapkan dalam pembelajaran IPA berintegrasi etnosains diperolah hasil bahwa yang menjawab semua konsep sebanyak $54 \%$, tumbuhan $3 \%$, ekosistem $15 \%$ dan sumber daya alam $28 \%$ sesuai dengan gambar 2

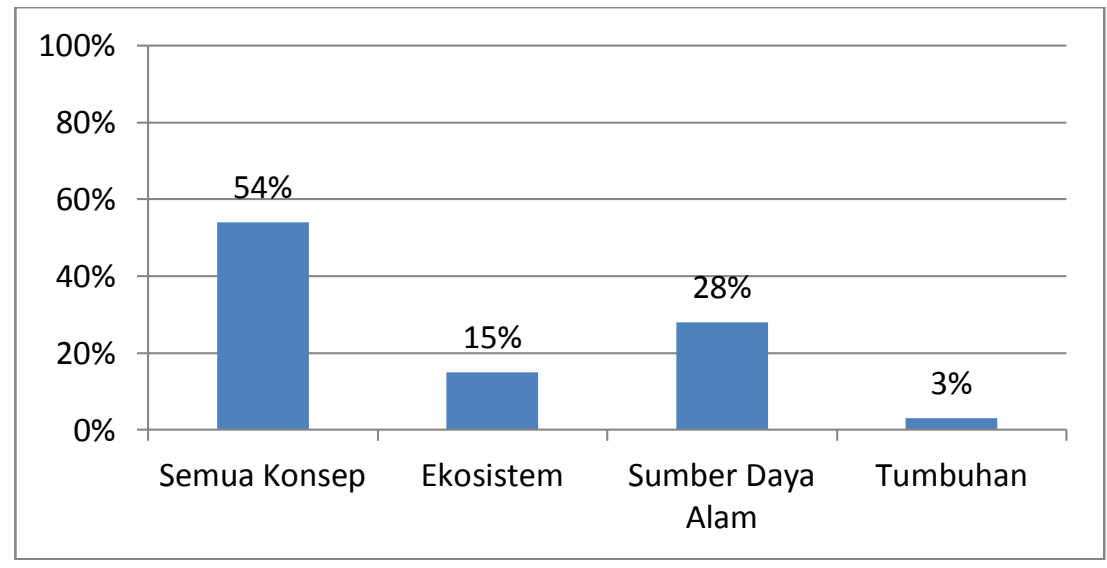

Gambar 2. Pokok bahasan yang dapat diterapkan pembelajaran berintegrasi etnosains

Berbagai materi dapat diajarkan menggunakan pembelajaran IPA berbasis etnosains. Materi yang diajarkan antara lain terkait materi yang terkait pemanfaatan 
sumber daya alam dan ekosistem (Ernawati, Azrai, \& Wibowo, 2016); (Nasihuddin, 2017); (Hidayati, 2019); (Esmiyani, Haryani, \& Purwantoyo, 2013). Semua konsep dapat juga digunakan dalam pembelajaran IPA berintegrasi etnosains tergantung dari guru dalam mengolah kegiatan pembelajaran. Topik yang dapat diajarkan misalnya adalah tentang bahan makanan (Rosyidah, Sudarmin, \& Siadi, 2013); konsep energi (Rahayu \& Sudarmin, 2015), dan materi bunyi dan gelombang (Dinissjah \& Risdianto, 2019), bahasa daerah (Mulyani, W, \& Hendri, 2013).

Aspek ketiga yaitu metode pembelajaran yang sesuai untuk pembelajaran IPA berbasis etnosains adalah bahwa ceramah sebesar 5\%, observasi $95 \%$

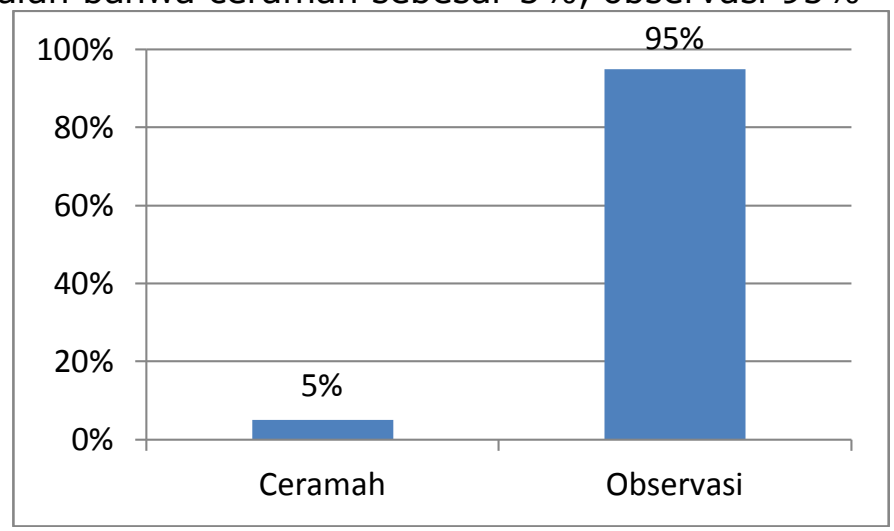

Gambar 3. Metode pembelajaran IPA berintegrasi etnosains

Berbagai metode pembelajaran dapat digunakan untuk melaksanakan pembelajaran IPA berbasis etnosains. Metode yang banyak dilakukan adalah dengan mengadakan observasi dan pengamatan langsung di lingkungan. Pembelajaran dengan mengamati proses produksi garam di tambak garam(Hadi \& Ahied, 2017); pengamatan pada proses pembuatan tempe pada pengrajin tempe (Atmojo, 2012);observasi langsung pada pembuatan gula kelapa (Sumarni, Sudarmin, Wiyanto, \& Supartono, 2016).

Aspek keempat yaitu sumber belajar yang dipergunakan dalam kegiatan pembelajaran IPA berintegrasi etnosains adalah lingkungan $54 \%$, buku teks $26 \%$ dan budaya masyarakat $20 \%$

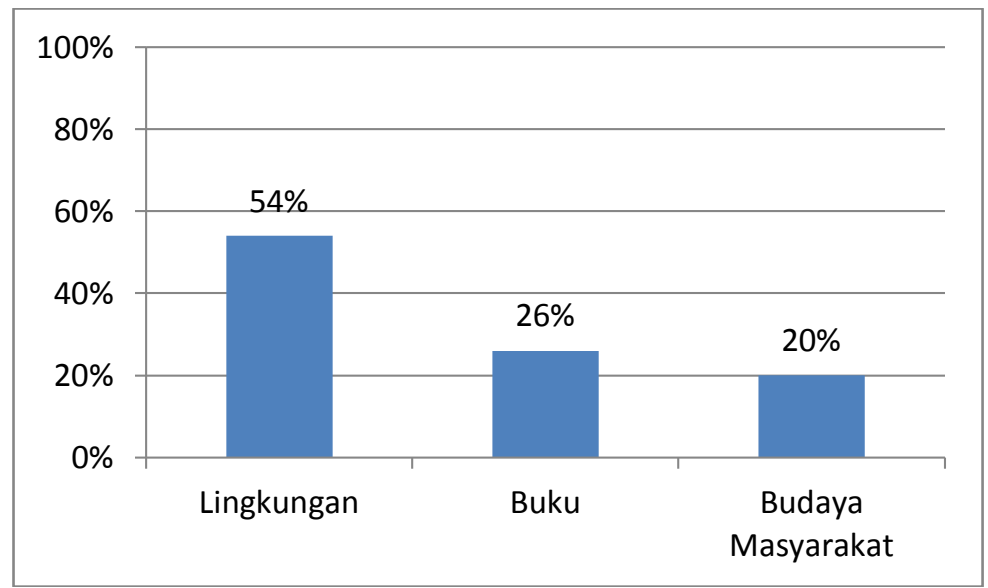

Gambar 4. Sumber pembelajaran IPA berintegrasi etnosains

Sumber belajar IPA yang paling banyak digunakan sebagai sumber pembelajaran IPA adalah dari lingkungan masyarakat sekitar. Kegiatan masyarakat dapat diamati langsung oleh siswa. Budaya masyarakat berupa seni musik dapat digunakan sebagai sumber belajar siswa yang dapat meningkatkan motivasi siswa(Zaitun, 2019), buku juga dapat digunakan sebagai sumber pembelajaran(Ardianti, Wanabuliandari, Saptono, \& Alimah, 2019); (Sarini \& Selamet, 2019); (Fitria \& Widi, 2015). Ekosistem juga digunakan untuk menjelaskan kaitan dengan etnosains (Sangha et al., 2018) 
Aspek kelima yaitu model kegiatan pembelajaran yang dipergunakan dalam kegiatan pembelajaran yaitu semua model dapat dipergunakan $20 \%$, STS $12 \%$, PjBL $3 \%$, pendekatan scientific $65 \%$

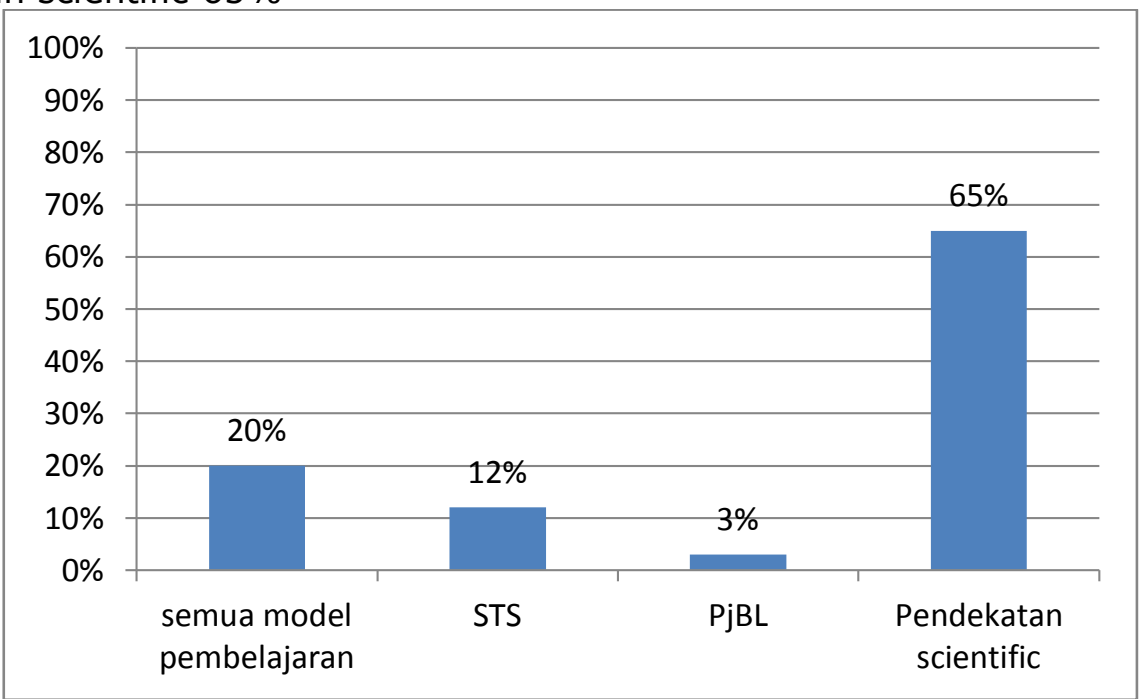

Gambar 5. Rancangan kegiatan pembelajaran

Model pembelajaran yang digunakan untuk penerapan pembelajaran etnosains dapat menggunakan berbagai macam model pembelajaran. Model pembelajaran yang digunakan antara lain adalah model terintegrasi etnosains (Damayanti, Rusilowati, \& Linuwih, 2017)

Aspek keenam yaitu terkait teknik penilaian yang dapat dilakukan dalam kegiatan pembelajaran adalah portofolio $40 \%$, tes tulis $12 \%$, unjuk kerja $48 \%$. ditunjukkan dalam gambar 6 sebagai berikut

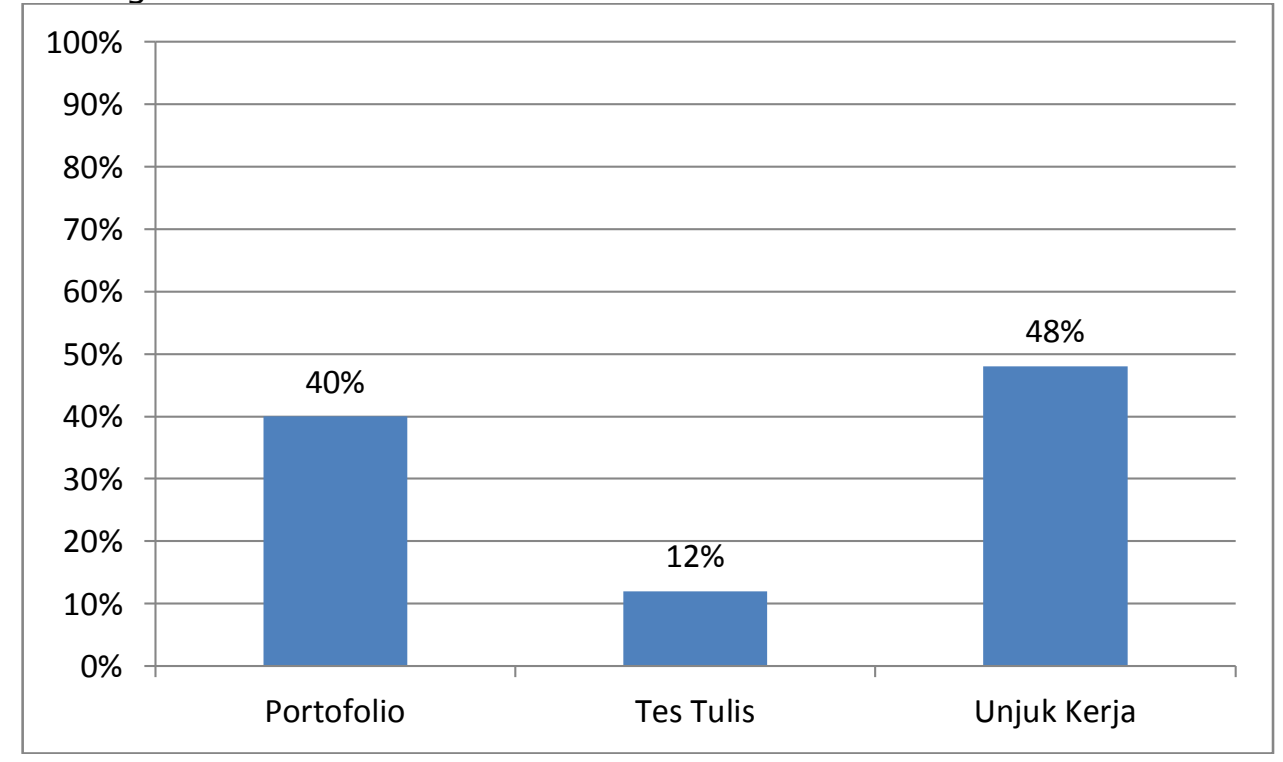

Penilaian pembelajaran dapat dilakukan dengan menggunakan berbagai penilaian (Toharudin \& Kurniawan, 2017), tes tulis (Agustin, Susilogati, \& Addiani, 2018). Portofolio juga telah banyak digunakan dalam evaluasi pembelajaran (Chairunisa, 2018); (Rini \& Fitriah, 2018)

\section{KESIMPULAN}

Penelitian yang telah dilakukan menunjukkan bahwa guru sudah merasa mudah menerapkan kegiatan pembelajaran IPA berintegrasi etnosains. Semua kompetensi 
dapat dikembangkan untuk di pembelajaran berintegrasi etnosains,metode observasi, dan sumber belajar dari lingkungan dan pendekatan scientific dapat digunakan untuk dalam melaksanakan pembelajaran. Teknik penilaian yang sesuai dengan pembelajaran berntegrasi etnosains adalah portofolio

\section{SARAN}

Penelitian selanjutnya adalah dengan mengimplementasikan kegiatan pembelajaran IPA berintegrasi etnosains dan mengembangkan berbagai bahan ajar untuk diterapkan di berbagai jenjang pendidikan

\section{REFERENSI}

Agustin, N., Susilogati, S., \& Addiani, K. (2018). Desain instrumen tes bermuatan etnosains untuk mengukur kemampuan berpikir kritis siswa sma. Jurnal Inovasi Pendidikan Kimia, 12(2), 2159-2169.

Anisa, M., Nanna, Mi. I., Sofyan, A., \& Kusnadi, D. (2019). Pengembangan Profesionalisme Guru Melalui Pelatihan Pengembangan Tes, Konstruksi dan Analisis Butir Soal di Wilayah 2T. LENSA (Lentera Sains): Jurnal Pendidikan IPA, 9(2), 4651.

Ardianti, S. D., Wanabuliandari, S., Saptono, S., \& Alimah, S. (2019). A Needs Assessment Of Edutainment Module With Ethnoscience Approach Oriented To The Love Of The Country. Jurnal Pendidikan IPA Indonesia, 8(2), 153-161. https://doi.org/10.15294/jpii.v8i2.13285

Atmojo, S. E. (2012). Profil Keterampilan Proses Sains dan Apresiasi Siswa Terhadap Profesi Pengrajin Tempe Dalam Pembelajaran IPA Berpendekatan Etnosains. Jurnal Pendidikan IPA Indonesia, 1(2), 115-122.

Chairunisa, E. D. (2018). Penilaian Portofolio Dalam Meningkatkan Kemampuan Self Assessment Mahasiswa. Kalpataru, 4(1), 83-88.

Damayanti, C., Rusilowati, A., \& Linuwih, S. (2017). Pengembangan Model Pembelajaran IPA Terintegrasi Etnosains untuk Meningkatkan Hasil Belajar dan Kemampuan Berpikir Kreatif. Journal of Innovative Science Education, 6(1), 116-128.

Dinissjah, M. J., \& Risdianto, E. (2019). Penggunaan Model Pembelajaran Direct Instruction Berbasis Etnosains Dalam Pembelajaran Fisika Untuk Meningkatkan Kemampuan Berpikir Kritis Siswa. Jurnal Kumparan Fisika, 2(2), 99-104.

Ernawati, Azrai, E. P., \& Wibowo, S. S. (2016). Hubungan Persepsi Kearifan Lokal Dengan Sikap Konservasi Masyarakat Desa Lencoh Kecamatan Selo Di Taman Nasional Gunung Merapi. Biosfer: Jurnal Pendidikan Biologi (biosferjpb ), 9(1), 6569.

Esmiyani, Haryani, S., \& Purwantoyo, E. (2013). Pengembangan Modul IPA Terpadu Bervisi SETS (Science, Environment, Technology, And Society) Pada Tema Ekosistem. Unnes Science Education Journal, 2(1), 180-187.

Fitria, M., \& Widi, A. (2015). The Development of Ethnoscience-Based Chemical Enrichment Book as a Science Literacy Source of Students, 2, 50-57.

Hadi, W. P., \& Ahied, M. (2017). Kajian Etnosains Madura dalam Proses Produksi Garam sebagai Media Pembelajaran IPA Terpadu. Jurnal Rekayasa, 10(2), 79-86. 
Hadi, W. P., Sari, F. P., Sugiarto, A., \& Mawaddah, W. (2019). Terasi Madura: Kajian Etnosains Dalam Pembelajaran Ipa Untuk Menumbuhkan Nilai Kearifan Lokal Dan Karakter Siswa. QUANTUM: Jurnal Inovasi Pendidikan Sains, 10(1), 45-55.

Hidayati, Y. (2019). Analysis Of Local Wisdom Toward Environmental Conservation Attitude In Bangkalan District: A Preliminary Researsch . Pena Sains, 6(1).

Hidayati, Y., Yasir, M., Qomaria, N., \& Fikriyah, A. (2019). Etnosains Kearifan Lokal Madura. Surakarta: CV Oase Group.

Mulyani, S., W, S. H., \& Hendri, Z. (2013). Pengembangan Model Bahan Ajar Berbasis Potensi Daerah Untuk Menunjang Pembelajaran Bahasa Jawa. Jurnal Kependidikan, 43(1), 51-60.

Nasihuddin, A. A. (2017). Kearifan lokal dalam perlindungan dan pengelolaan lingkungan hidup (studi di desa janggolan, banyumas). Bina Hukum Lingkungan, 2(1), 18-20. https://doi.org/10.24970/jbhl.v2n1.9

NM, N. A., Susilawati, \& Patonah, S. (2011). Kajian kompetensi profesional guru ipa di smp kota semarang 1. JP2F, 2(September), 124-132.

Rahayu, W. E., \& Sudarmin. (2015). Pengembangan Modul Ipa Terpadu Berbasis Etnosains Tema Energi Dalam Kehidupan Untuk Menanamkan Jiwa Konservasi Siswa. Unnes Science Education Journal, 4(2).

Rahman, M. H. (2016). Kompetensi Guru Ipa Smp Pulau Bacan Kabupaten Halmahera Selatan. Jurnal Penelitian Humano, 7(2), 207-216.

Rini, C. P., \& Fitriah. (2018). Penilaian Berbasis Portofolio Siswa Kelas V. In Prosiding Seminar dan Diskusi Nasional Pendidikan Dasar (pp. 88-93).

Rosyidah, A. N., Sudarmin, \& Siadi, K. (2013). Pengembangan Modul IPA Berbasis Etnosains Zat Aditif Dalam Bahan Makanan Untuk Kelas VIII SMP Negeri 1 Pegandon Kendal. Unnes Science Education Journal, 2(1), 133-139.

Sangha, K. K., Preece, L., Villarreal-rosas, J., Kegamba, J. J., Paudyal, K., Warmenhoven, T., \& Ramakrishnan, P. S. (2018). An ecosystem services framework to evaluate indigenous and local peoples' connections with nature. Ecosystem Services, 31, 111-125. https://doi.org/10.1016/j.ecoser.2018.03.017

Sarini, P., \& Selamet, K. (2019). Pengembangan Bahan Ajar Etnosains Bali bagi Calon Guru IPA. Wahana Matematika Dan Sains: Jurnal Matematika,Sains, Dan Pembelajarannya, 13(1), 27-39.

Septiasari, R. (2019). Pemetaan Pengetahuan Etnosains Guru Sekolah Dasar di Kecamatan Muara Bulian. Universitas Jambi.

Suastra, I. W. (2010). Model Pembelajaran Sains Berbasis Budaya Lokal Untuk Mengembangkan Kompetensi Dasar Sains dan Nilai Kearifan Lokal di SMP. Jurnal Pendidikan Dan Pengajaran, 43(2), 8-16.

Suastra, I. W., Jatmiko, B., Ristiati, N. ., \& Yasmini, L. P. B. (2017). Developing Characters Based On Local Wisdom Of Bali In Teaching Physics In Senior High School. Jurnal Pendidikan IPA Indonesia, 6(2), 306-312. https://doi.org/10.15294/jpii.v6i2.10681

Sumarni, W., Sudarmin, Wiyanto, \& Supartono. (2016). The reconstruction of society 
indigenous science into scientific knowledge in the production process of palm sugar. Journal of Turkish Science Education, 13(4), 281-292. https://doi.org/10.12973/tused.10185a

Toharudin, U., \& Kurniawan, I. S. (2017). Values of Local Wisdom: A Potential to Develop an Assessment and Remedial. International Journal of Evaluation and Research in Education, 6(1), 71-78.

Yuliana, I. (2017). Pembelajaran Berbasis Etnosains Dalam Mewujudkan Pendidikan Karakter Siswa Sekolah Dasar. ELSE (Elementary School Education Journal): Jurnal Pendidikan Dan Pembelajaran Sekolah Dasar, 1(2015), 98-106.

Zaitun. (2019). The Benefits Of Learning Motivation Based On Local Of G12. EduHumaniora: Jurnal Pendidikan Dasar, 11(1), 36-45. 